\author{
Marquette University \\ e-Publications@Marquette
}

7-2007

\title{
The Voltammetric Study of the Reduction of Tetraalkylammonium Perchlorate by Fe(TPP) ${ }^{2-}$
}

Chathra Shirani De Silva

Marquette University

Michael D. Ryan

Marquette University, michael.ryan@marquette.edu

Follow this and additional works at: https://epublications.marquette.edu/chem_fac

Part of the Chemistry Commons

\section{Recommended Citation}

De Silva, Chathra Shirani and Ryan, Michael D., "The Voltammetric Study of the Reduction of Tetraalkylammonium Perchlorate by Fe(TPP) ${ }^{2-" ~(2007) . ~ C h e m i s t r y ~ F a c u l t y ~ R e s e a r c h ~ a n d ~ P u b l i c a t i o n s . ~}$ 168.

https://epublications.marquette.edu/chem_fac/168 


\title{
The Voltammetric Study of the Reduction of Tetraalkylammonium Perchlorate by Fe(TPP) ${ }^{2-}$
}

\author{
Michael D. Ryan \\ Chemistry, Marquette University \\ Milwaukee, WI \\ Chathra DeSilva \\ Chemistry, Marquette University \\ Milwaukee, WI
}

\begin{abstract}
Tetraalkylammonium ions react with FeTPP2- to form Fe(TPP)(R)and trialkylamine. The tetrabutylammonium cation was verified to be the source of the alkyl group in the product, (TPP) (R)-, by using $\left({ }^{1} \mathrm{H}_{5} \mathrm{C}_{2}\right)_{3}\left({ }^{2} \mathrm{H}_{5} \mathrm{C}_{2}\right) \mathrm{N}^{+}$ as the cation and ${ }^{2} \mathrm{H}$ NMR. The reaction of FeTPP ${ }^{2-}$ with $\mathrm{Bu}_{4} \mathrm{~N}^{+}$was monitored by cyclic voltammetry and thin layer spectroelectrochemistry. The activation parameters were measured, and were most consistent with an electron transfer (ET) mechanism. The rate of the reaction of tetramethyl and tetraethylammonium ions with $\mathrm{Fe}(\mathrm{TPP})^{2-}$ was also examined. The rate constant decreased significantly as the carbon chain length decreased, which was also consistent with an ET mechanism.
\end{abstract}

\section{Introduction}

Tetraalkylammonium ions are commonly used supporting electrolytes in voltammetric studies. They are generally considered to be resistant to reduction, but a few reports have indicated their reactivity $[1,2,3]$. The initial work by DeSilva et al. in our laboratory has shown that 
iron("0") porphyrins are capable of reducing tetraalkylammonium ions while forming iron(II) porphyrin alkyls [1]. There have been a number of reports on the electrochemical or photochemical reduction of tetraalkylammonium salts. Aurbach and Gottlieb found that the direct reduction of the tetrabutylammonium ion $\left(\mathrm{TBA}^{+}\right)$at a gold electrode lead to the reductive cleavage of the $\mathrm{C}-\mathrm{N}$ bond to form tributylamine and butyl radical [2]. Later Dahm and Peters studied the electrochemical reduction of tetraalkylammonium salts at a carbon electrode and found similar results [4]. Kunkely and Vogler studied the photochemical reaction of tetrabutylammonium tetrabutylborate and found that octane was the major hydrocarbon product [5].

Iron("0") porphyrins are quite reactive species which can react by either nucleophilic substitution $\left(\mathrm{S}_{\mathrm{N}} 2\right)$ or by single electron transfer (ET) processes. Iron(I) and iron(" 0 ") porphyrins have been shown to react with a variety of substrates including alkyl halides $[6,7]$, carboxylic anhydrides [8], carbon dioxide $[9,10,11]$ and weak acids to generate $\mathrm{H}_{2}$ [12]. The reaction between iron(I) or iron("0") porphyrins with alkyl halides has been studied most extensively in order to investigate the competition between $S_{N} 2$ and ET mechanisms $[13,14]$. Both processes were observed depending upon the temperature and structures of the substrates. These previous reports have emphasized the nucleophilic character of iron("0") porphyrins.

The dealkylation of tetraalkylammonium salts has been examined using halide ions are the nucleophile. The reactivity trend in molten salts and in solution was consistent with nucleophilic attack on tetraalkylammonium ions $[15,16]$. As reported previously, $\mathrm{Fe}(\mathrm{TPP})^{2-}$ has been similarly shown to dealkylated the tetraalkylammonium ion. Steric would be expected to favor the ET over the $\mathrm{S}_{\mathrm{N}} 2$ mechanism. But, for small cations such as tetramethylammonium ion $\left(\mathrm{TMA}^{+}\right)$or tetraethylammonium $\left(\mathrm{TEA}^{+}\right)$, one might expect a change to an $\mathrm{S}_{\mathrm{N}} 2$ mechanism. Following up on our initial report on the formation of the iron porphyrin alkyls from iron("0") porphyrins, work continued in our laboratory to confirm that the reaction of $\mathrm{Fe}(\mathrm{TPP})^{2-}$ was indeed an ET reaction, and to determine whether smaller tetraalkylammonium cations led to a change in mechanism. This study would help to understand the nucleophilic properties of iron("0") porphyrins.

Journal of Porphyrins and Phthalocyanines, Vol. 11, No. 7 (2007): pg. 519-523. DOI. This article is (C) Wiley and permission has been granted for this version to appear in e-Publications@Marquette. Wiley does not grant permission for this article to be further copied/distributed or hosted elsewhere without the express permission from Wiley. 


\section{Experimental}

\section{Chemicals}

Chlorin-free iron(III) tetraphenylporphyrin chloride was purchased from MidCentury Chemicals, and was used as received. Dimethylformamide (DMF) (Aldrich Chemical Co.) was purified by heating at reflux temperatures over calcium hydride, followed by distillation under reduced pressure. Care has been taken to avoid exposure to the atmosphere by flushing the receiving containers with argon gas. All solvents were stored in an argon atmosphere. Tetramethylammonium (TMAP), tetraethylammonium (TEAP) and tetrabutylammonium (TBAP) perchlorate was obtained from GFS Chemical Co. Partially deuterated TBAP ( $d_{9}$-TBAP, Isotec Inc, $99.9 \%$ ${ }^{2} \mathrm{H}$ ) was synthesized using the method of Missan et al.[17] with $d_{9}$ butyl bromide replacing natural abundance butyl bromide. The crude product was recrystallized from anhydrous ethyl acetate[18]. Deuteration was then verified by ${ }^{2} \mathrm{H}$ NMR.

\section{Instrumentation}

The cyclic voltammetric data were obtained with a Cypress System CYSY-1R potentiostat (Version 6.0 software). A three electrode cell was used for voltammetric measurements, consisting of a platinum wire or flag working electrode, a platinum flag auxiliary electrode, and a $\mathrm{Ag} / 0.1 \mathrm{M} \mathrm{AgNO}_{3}$ in acetonitrile reference electrode. The reference electrode was separated from the electrochemical test solution by a salt bridge filled with the appropriate solvent and supporting electrolyte. Digital simulations were carried out using Digisim 3 (Bioanalytical Systems). In the simulations, the diffusion coefficients of all species were assumed to be equal. The UV-visible spectra were recorded on a Hewlett-Packard 8452A diode array spectrophotometer. Controlled potential electrolysis were performed with an Electrosynthesis Co. Model 410 potentiostatic controller with an EG\&G PARC model 379 digital coulometer. An OTTLE cell as described by Lin and Kadish was used for the spectroelectrochemical data [19].

Journal of Porphyrins and Phthalocyanines, Vol. 11, No. 7 (2007): pg. 519-523. DOI. This article is (c) Wiley and permission has been granted for this version to appear in e-Publications@Marquette. Wiley does not grant permission for this article to be further copied/distributed or hosted elsewhere without the express permission from Wiley. 


\section{Results and Discussion}

The electrochemical reduction of $\mathrm{Fe}(\mathrm{TPP}) \mathrm{Cl}$ has been extensively studied and occurs in three reversible waves:

$$
\begin{array}{lr}
\mathrm{Fe}^{\mathrm{III}}(\mathrm{TPP}) \mathrm{Cl}+\mathrm{e}^{-} \rightleftharpoons \mathrm{Fe}^{\mathrm{II}}(\mathrm{TPP})+\mathrm{Cl}^{-} & \text {Wave } 1 \\
\mathrm{Fe}^{\mathrm{II}}(\mathrm{TPP})+\mathrm{e}^{-} \rightleftharpoons \mathrm{Fe}^{\mathrm{I}}(\mathrm{TPP})^{-} & \text {Wave } 2 \\
\mathrm{Fe}^{\mathrm{I}}(\mathrm{TPP})^{-}+\mathrm{e}^{-} \rightleftharpoons \mathrm{Fe}(\mathrm{TPP})^{2-} & \text { Wave } 3
\end{array}
$$

The product of Wave 3 is formally an iron("0") porphyrin but has considerable iron(I) porphyrin radical anion character. If the working electrode potential is poised for $3 \mathrm{~min}$ at a potential beyond the $3^{\text {rd }}$ wave at room temperature, the appearance of new waves due to the alkylated iron porphyrin can be readily observed [1]. The following reaction was showed to have occurred:

$$
\begin{array}{ll}
\mathrm{Fe}(\mathrm{TPP})^{2-}+\mathrm{R}_{4} \mathrm{~N}^{+} \rightarrow \mathrm{Fe}^{\mathrm{II}}(\mathrm{TPP})(\mathrm{R})^{-}+\mathrm{R}_{3} \mathrm{~N} & \text { Reaction 1 } \\
\mathrm{Fe}^{\mathrm{II}}(\mathrm{TPP})(\mathrm{R})^{-} \rightarrow \mathrm{Fe}^{\mathrm{III}}(\mathrm{TPP})(\mathrm{R})+\mathrm{e}^{-} & \text {Wave 4' } \\
\mathrm{Fe}^{\mathrm{III}}(\mathrm{TPP})(\mathrm{R}) \rightarrow \mathrm{Fe}^{\mathrm{IV}}(\mathrm{TPP})(\mathrm{R})^{+}+\mathrm{e}^{-} & \text {Wave 5' }
\end{array}
$$

where the prime waves indicate oxidation peaks, the unprimed waves indicate reduction peaks and $\mathrm{k}$ is the rate constant for Reaction 1. At elevated temperatures (above $47^{\circ} \mathrm{C}$ ), Wave $4^{\prime}$ can be readily observed in the cyclic scan (Figure 1B). Resonance Raman, visible spectroscopy and voltammetry have all shown that an alkyl iron porphyrin was formed [1]. No alkyl porphyrins were observed when the potential was held between Waves 2 and 3 (formation of $\mathrm{Fe}(\mathrm{TPP})^{-}$). In order to 
exclude the solvent as the source of the alkyl group and to positively verify $\mathrm{TBA}^{+}$as the source of the akyl group, deuterated TBAP was synthesized ( $\left.d_{9}-T B A P\right)$. For synthetic simplicity, only one of the alkyl groups was deuterated, as the $d_{9}$-TBAP was formed from the reaction of natural abundance tributyl amine and $d_{9}$-butyl bromide. Electrolysis of $4.0 \mathrm{mM}$ FeTPPCl in THF and $0.050 \underline{\mathrm{M}} \mathrm{d}_{9}$-TBAP was carried out at -2.3 $\mathrm{V}$ vs $\mathrm{Ag} / \mathrm{AgClO}_{4}$ reference electrode. The reduced solution was characterized by ${ }^{2} \mathrm{H}$ NMR. The results are summarized in Table 1 , along with literature values as obtained by proton NMR. The results conclusively show that the supporting electrolyte is the source of the alkyl group.

Alkylation of iron porphyrins can occur by $E T$ or $S_{N} 2$ processes. These processes can be distinguished by the determination of the activation parameters for Reaction 1 . The products of the first two waves (Fe $\left.\mathrm{FI}^{\mathrm{II}}(\mathrm{TPP}), \mathrm{Fe}^{\mathrm{I}}(\mathrm{TPP})^{-}\right)$are stable on the cyclic voltammetric time scale. The rate of Reaction 1 can be determined from the peak current ratio for the third wave $\left(i_{p r} / i_{p f}\right.$, where $i_{p r}=$ current due to the reverse wave corrected for the Cottrell decay of the forward wave, and $i_{\mathrm{pf}}=$ current due to the forward wave corrected for the Cottrell decay of the 2nd wave). A typical comparison of the experimental and simulated cyclic voltammograms are shown in Figure 1 for $k=2.0 \underline{M}^{-1} \mathrm{~s}^{-1}$, using a pseudo-first order mechanism with respect to $\mathrm{TBA}^{+}$. The decrease in current for Wave $3^{\prime}$ can be seen in both the simulated and experimental cyclic voltammograms, as well as the new peak for Wave $4^{\prime}$ due to the oxidation of $\mathrm{Fe}(\mathrm{TPP})(\mathrm{Bu})^{-}$(the poor fit to the reverse peak of Wave 1 is due to ligand kinetics which is not of relevance to this work). The peak current ratios for five temperatures are summarized in Table 2 . Using the peak current ratios, the rate constants can be calculated [20] and the results are summarized in Figure 2.

The rate constant at room temperature was determined using spectroelectrochemistry as the reaction was too slow to be observed using cyclic voltammetry. The electrode potential was poised at $-2.3 \mathrm{~V}$, and the absorbance for Fe(TPP) ${ }^{2-}$ at $460 \mathrm{~nm}$ was monitored as a function of time in a thin-layer spectroelectrochemical cell. Linear pseudo-first order reaction kinetics were observed and a rate constant of $0.13 \mathrm{M}^{-1} \mathrm{~S}^{-1}$ was found. The enthalpy and entropy of activation were

Journal of Porphyrins and Phthalocyanines, Vol. 11, No. 7 (2007): pg. 519-523. DOI. This article is @ Wiley and permission has been granted for this version to appear in e-Publications@Marquette. Wiley does not grant permission for this article to be further copied/distributed or hosted elsewhere without the express permission from Wiley. 
obtained from the Arrhenius plot, and the entropy of activation was found using the following equation [13]:

$$
\ln \mathrm{k}=\ln \mathrm{Z}-\left(\Delta \mathrm{H}^{\neq} / \mathrm{RT}\right)+\left(\Delta \mathrm{S}^{\neq} / \mathrm{R}\right)
$$

where $Z$ is the collision frequency and estimated to be $3 \times 10^{11} \mathrm{M}^{-1} \mathrm{~s}^{-1}$ [13]. Using this equation and the Arrhenius plot, the $\Delta H^{\neq}=15 \pm 1 \mathrm{kcal}$ and $\Delta S^{\neq}=-7 \pm 2 \mathrm{cal} / \mathrm{K}$

The reaction of Fe(TPP) $)^{2-}$ with tetraethylammonium $\left(\mathrm{TEA}^{+}\right)$and tetramethylammonium $\left(\mathrm{TMA}^{+}\right)$ions was also examined. Slow scan rate cyclic voltammograms of $\mathrm{Fe}(\mathrm{TPP}) \mathrm{Cl}$ in DMF with $0.10 \underline{\mathrm{M}}$ tetraalkylammonium perchlorate are shown in Figure 3. From the cyclic voltammograms, it is clear that the reaction of $\mathrm{TEA}^{+}$with $\mathrm{Fe}(\mathrm{TPP})^{2-}$ is significantly slower than the reaction with $\mathrm{TBA}^{+}$, and an even slower reaction (if at all) could be observed with $\mathrm{TMA}^{+}$. In fact, in the presence of $\mathrm{TMA}^{+}$, the $\mathrm{Fe}(\mathrm{I}) / \mathrm{Fe}\left(" \mathrm{O}^{\prime \prime}\right)$ was nearly chemical reversible indicating either no reaction or a slow reaction between $\mathrm{Fe}(\mathrm{TPP})^{2-}$ and $\mathrm{TMA}^{+}$. Using thin-layer spectroelectrochemistry, the rate of the reaction between the tetraalkylammonium ion and FeTPP ${ }^{2-}$ at room temperature was measured. The rate constant for TEA ${ }^{+}$with $\mathrm{Fe}(\mathrm{TPP})^{2-}$ was found to be $1.15 \pm 0.02 \times 10^{-2} \mathrm{M}^{-1} \mathrm{~s}^{-1}$, compared to 0.13 $\mathrm{M}^{-1} \mathrm{~S}^{-1}$ for TBA ${ }^{+}$under the same conditions. With $\mathrm{TMA}^{+}$, the rate constant decreased to $7.2 \pm 0.6 \times 10^{-3} \underline{\mathrm{M}}^{-1} \mathrm{~s}^{-1}$.

In Table 3 the activation parameters for the reaction of low valent iron porphyrins with substrate are summarized. The previously studied reactions of iron porphyrins with alkyl halides are more similar to the Menschutkin type reactions in which alkyl amines react with alkyl halides to form ionic products.

$$
\mathrm{R}_{3} \mathrm{~N}+\mathrm{R}^{\prime} \mathrm{X} \rightarrow \mathrm{R}_{3} \mathrm{R}^{\prime} \mathrm{N}^{+}+\mathrm{X}^{-}
$$

these cases, the origin of the large negative values of $\Delta S$ and $\Delta S^{\neq}$is the electrostatic solvation of the charges formed [21]. Both these values are large and negative, and the solvation effects dominate over the translational entropy of bringing the reactants together

Journal of Porphyrins and Phthalocyanines, Vol. 11, No. 7 (2007): pg. 519-523. DOI. This article is (c) Wiley and permission has been granted for this version to appear in e-Publications@Marquette. Wiley does not grant permission for this article to be further copied/distributed or hosted elsewhere without the express permission from Wiley. 
NOT THE PUBLISHED VERSION; this is the author's final, peer-reviewed manuscript. The published version may be accessed by following the link in the citation at the bottom of the page.

[21]. In Reaction 1 above, there is a decrease in solvation as a cation and a dianion react to form a mono-cation and neutral species. This reaction is more similar to a reverse Menschutkin reaction, which has been shown for pyridines to have positive $\Delta S^{\neq}$, reflective of the $\Delta S$ for the reaction.

An examination of the activation enthalpies and entropies can provide insight into the ET and $\mathrm{S}_{\mathrm{N}} 2$ reaction pathways. As was stated above, solvation changes will dominate the transition state for the $\mathrm{S}_{\mathrm{N}} 2$ type reaction, leading to large negative or positive entropies of activation, depending upon whether ionic compounds are formed (large negative entropy) or charges are reduced (positive entropies). But relatively smaller values of $\Delta \mathrm{H}^{\neq}$are observed because of the concerted bond-breaking/bond-making process [13] (it should be noted that the reverse Menschutkin reaction for alkyl pyridiniums have a large $\Delta \mathrm{H}^{\neq}$, which is due to the endothermic and non-spontaneous nature of this reaction for alkyl halides and trialkylamines) [21]. In a similar manner, the ET mechanism, which is an outer sphere process, requires less organization in the transition state, but much higher values for $\Delta \mathrm{H}^{\neq}$because of the bond breaking process. An examination of Table 3 indicates that the reaction of $\mathrm{Fe}(\mathrm{TPP})^{2-}$ with $\mathrm{TBA}^{+}$is most consistent with an ET mechanism.

A stronger confirmation of the ET mechanism was obtained from the variation in the alkyl group in the tetraalkylammonium salts. The rate of the reaction of tetraalkylammonium ions and FeTPP ${ }^{2-}$ is consistent with the stability of the alkyl radical that would be initially formed.

$$
\mathrm{R}_{4} \mathrm{~N}^{+}+\mathrm{e}^{-} \rightarrow \mathrm{R}^{\cdot}+\mathrm{NR}_{3}
$$

Since the reaction appears to be primarily an ET mechanism rather than an $\mathrm{S}_{\mathrm{N}} 2$ mechanism, the reaction rate would be controlled primarily by the energy required to break the $\mathrm{C}-\mathrm{N}$ bond and form the radical. If there were significant bond formation in the transition state due to the nucleophilic character of FeTPP2-, this should have been strongest for the $\mathrm{TMA}^{+}$ion because of the reduced steric hinderance in the transition state. The fact than tetramethylammonium ion reacts

Journal of Porphyrins and Phthalocyanines, Vol. 11, No. 7 (2007): pg. 519-523. DOI. This article is (c) Wiley and permission has been granted for this version to appear in e-Publications@Marquette. Wiley does not grant permission for this article to be further copied/distributed or hosted elsewhere without the express permission from Wiley. 
substantially slower than $\mathrm{TEA}^{+}$and $\mathrm{TBA}^{+}$is consistent with an ET mechanism.

\section{Conclusion}

Tetraalkylammonium ions react with $\mathrm{Fe}(\mathrm{TPP})^{2-}$ to form $\mathrm{Fe}(\mathrm{TPP})(\mathrm{R})^{-}$complexes and trialkylamines. The low value for $\Delta \mathrm{S} \neq$ and the high value for $\Delta \mathrm{H}^{\neq}$were most consistent with an ET mechanism instead of an $S_{N} 2$ mechanism. Steric factors probably reduce the ability of the low valent iron complexes, which are known to have nucleophilic character, to react by an inner sphere process. The rate of the reaction increased as the carbon chain length from methyl to butyl, which was also consistent with an ET mechanism, reflecting the stability of the alkyl radical that was initially formed. The reactivity of the tetraalkylammonium ions indicates that they should be avoided whenever iron("0") porphyrins are formed.

\section{Table 1}

\section{${ }^{1} \mathrm{H}$ and ${ }^{2} \mathrm{H}$ NMR Spectroscopy of Iron Alkyl Porphyrins}

\begin{tabular}{lllllll} 
Complex & Nuclei & $\delta$, & & & & Reference \\
& \multicolumn{5}{c}{$\mathrm{ppm}^{\mathrm{a}}$} \\
& $\alpha$ & $\beta$ & $\gamma$ & $\delta$ & \\
$\mathrm{Fe}(\mathrm{TPP})\left(\mathrm{CH}_{2} \mathrm{CH}_{3}\right)^{-}$ & ${ }^{1} \mathrm{H}$ & -6.19 & -2.25 & $\ldots$ & $\ldots$ & {$[22]$} \\
$\mathrm{Fe}(\mathrm{TPP})\left(\mathrm{CH}_{2} \mathrm{CH}_{2} \mathrm{CH}_{3}\right)^{-}$ & ${ }^{1} \mathrm{H}$ & -6.0 & -1.5 & -0.6 & $\ldots$ & {$[22]$} \\
$\mathrm{Fe}(\mathrm{TPP})\left(\mathrm{CH}_{2} \mathrm{CH}_{2} \mathrm{CH}_{2} \mathrm{CH}_{3}\right)^{-}$ & ${ }^{2} \mathrm{H}$ & -6.90 & -2.15 & -0.55 & +0.01 & This work
\end{tabular}


NOT THE PUBLISHED VERSION; this is the author's final, peer-reviewed manuscript. The published version may be accessed by following the link in the citation at the bottom of the page.

\section{Table 2}

\section{Variation of the Peak Current Ratios for Wave 3 \\ as a Function of Scan Rate and Temperature}

\begin{tabular}{llll} 
Temperature & \multicolumn{2}{l}{ Peak current ratios } & \\
Scan rate $(\mathrm{mV} / \mathrm{s})$ & 50 & 100 & 200 \\
$47^{\circ}$ & 0.65 & 0.79 & 0.86 \\
$55^{\circ}$ & 0.46 & 0.65 & 0.75 \\
$62^{\circ}$ & 0.46 & 0.58 & 0.68 \\
$65^{\circ}$ & 0.42 & 0.55 & 0.65 \\
$72^{\circ}$ & -- & 0.44 & 0.52
\end{tabular}

Solvent: DMF; working electrode: glassy carbon electrode; Electrolyte: $0.10 \underline{\mathrm{M}}$ TBAP 
NOT THE PUBLISHED VERSION; this is the author's final, peer-reviewed manuscript. The published version may be accessed by following the link in the citation at the bottom of the page.

\section{Table 3}

Activation Parameters for the Reaction of Low Valent Iron Porphyrins with Substrates

Electron do- substrate "ET" be- " $\mathrm{S}_{\mathrm{N}} 2$ " be- $\quad$ Reference nor havior $\quad \Delta \mathrm{S}^{*}, \mathrm{cal} / \mathrm{K}$ havior $\Delta \mathrm{S}^{*}, \mathrm{cal} / \mathrm{K}$

\begin{tabular}{|c|c|c|c|c|c|c|}
\hline \multirow[b]{2}{*}{$\mathrm{Fe}\left({ }^{*} 0^{\prime}\right)-$} & & \multicolumn{2}{|l|}{$\Delta \mathrm{H}^{+}, \mathrm{kcal}$} & \multicolumn{2}{|l|}{$\Delta \mathrm{H}^{*}, \mathrm{kcal}$} & \multirow[b]{2}{*}{ [13] } \\
\hline & $n$-butyl & -- & - & $2.3 \pm 0.4$ & $-21 \pm 2$ & \\
\hline \multirow[t]{5}{*}{ ETIO } & bromide & & & & & \\
\hline & sec-butyl & $11 \pm 2$ & $4 \pm 5$ & - & - & [13] \\
\hline & bromide & & & & & \\
\hline & $t$-butyl & $10.0 \pm 0.5$ & $-1.7 \pm 0.4$ & - & -- & [13] \\
\hline & bromide & & & & & \\
\hline $\mathrm{Fe}(" 0 ")-\mathrm{TPP}$ & $n$-butyl & -. & - & $3.4 \pm 0.9$ & $-22 \pm 3$ & [13] \\
\hline & bromide & & & & & \\
\hline $\mathrm{Fe}(\mathrm{I})$-OEP & n-butyl & -- & - & $6.5 \pm 0.8$ & $-22 \pm 3$ & [13] \\
\hline & bromide & & & & & \\
\hline $\mathrm{Fe}\left({ }^{*} 0^{* \prime}\right)-\mathrm{TPP}$ & $\mathrm{TBA}^{+}$ & $15 \pm 1$ & $-7 \pm 2$ & -- & - & this \\
\hline
\end{tabular}

Journal of Porphyrins and Phthalocyanines, Vol. 11, No. 7 (2007): pg. 519-523. DOI. This article is (C) Wiley and permission has been granted for this version to appear in e-Publications@Marquette. Wiley does not grant permission for this article to be further copied/distributed or hosted elsewhere without the express permission from Wiley. 
NOT THE PUBLISHED VERSION; this is the author's final, peer-reviewed manuscript. The published version may be accessed by following the link in the citation at the bottom of the page.

Figure 1. A. Simulated cyclic voltammogram. B. Experimental cyclic voltammogram at a glassy carbon electrode. Concentration of $\mathrm{Fe}(\mathrm{TPP}) \mathrm{Cl}: 0.50$ $\mathrm{m} \underline{\mathrm{M}}$, concentration of TBAP: $0.10 \underline{\mathrm{M}}$; solvent: DMF; scan rate: $100 \mathrm{mV} / \mathrm{s}$; reference electrode: $\mathrm{Ag} / \mathrm{AgClO}_{4}$ in acetonitrile; temperature: $55^{\circ}$.
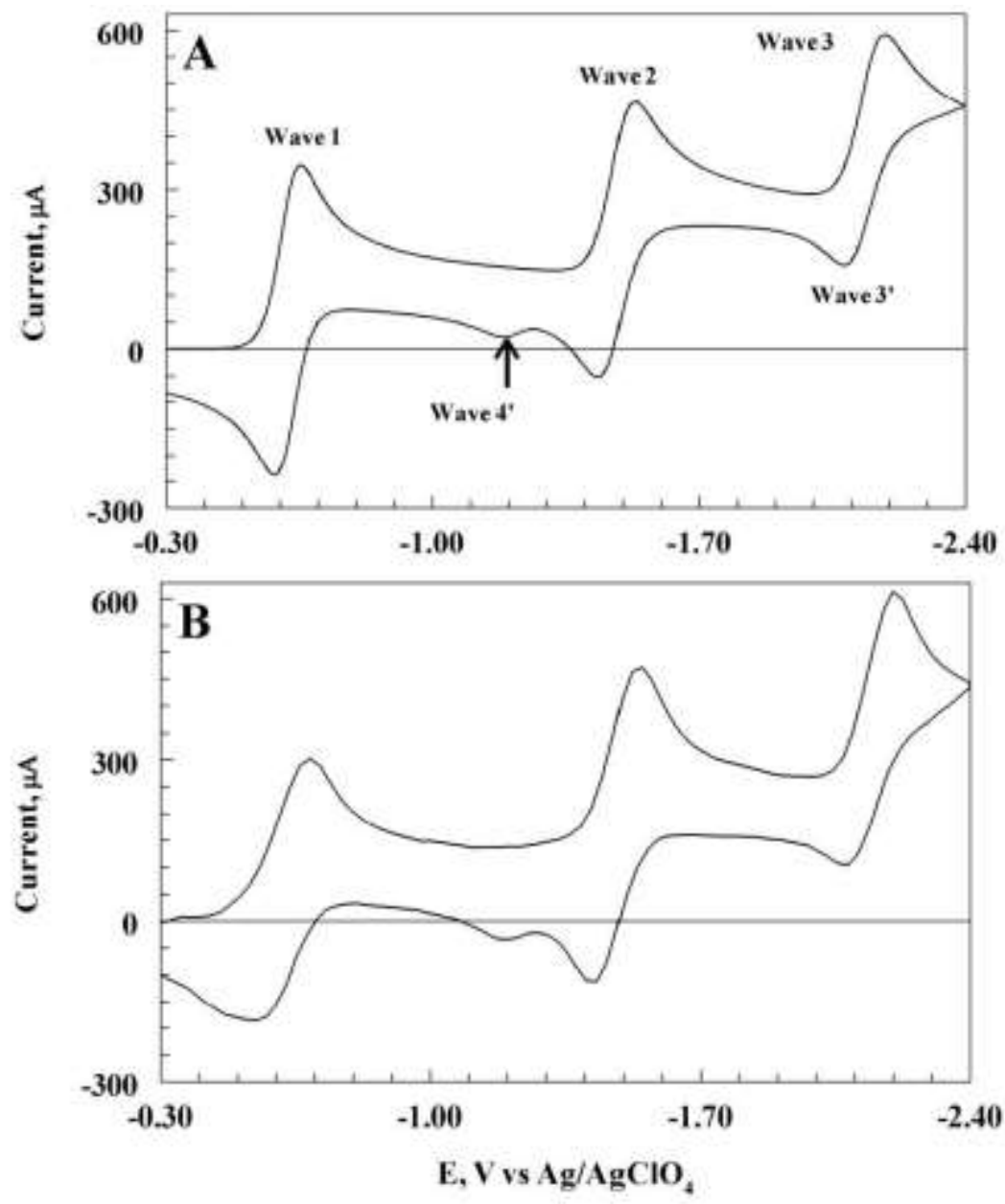

Journal of Porphyrins and Phthalocyanines, Vol. 11, No. 7 (2007): pg. 519-523. DOI. This article is (C Wiley and permission has been granted for this version to appear in e-Publications@Marquette. Wiley does not grant permission for this article to be further copied/distributed or hosted elsewhere without the express permission from Wiley. 
NOT THE PUBLISHED VERSION; this is the author's final, peer-reviewed manuscript. The published version may be accessed by following the link in the citation at the bottom of the page.

Figure 2. Arrhenius plot for the reaction of $F e(T P P)^{2-}$ with $\mathrm{TBA}^{+}$in DMF. Filled triangles: rate constants determined from cyclic voltammetry. Filled circle: rate constant determined from thin-layer spectroelectrochemistry.

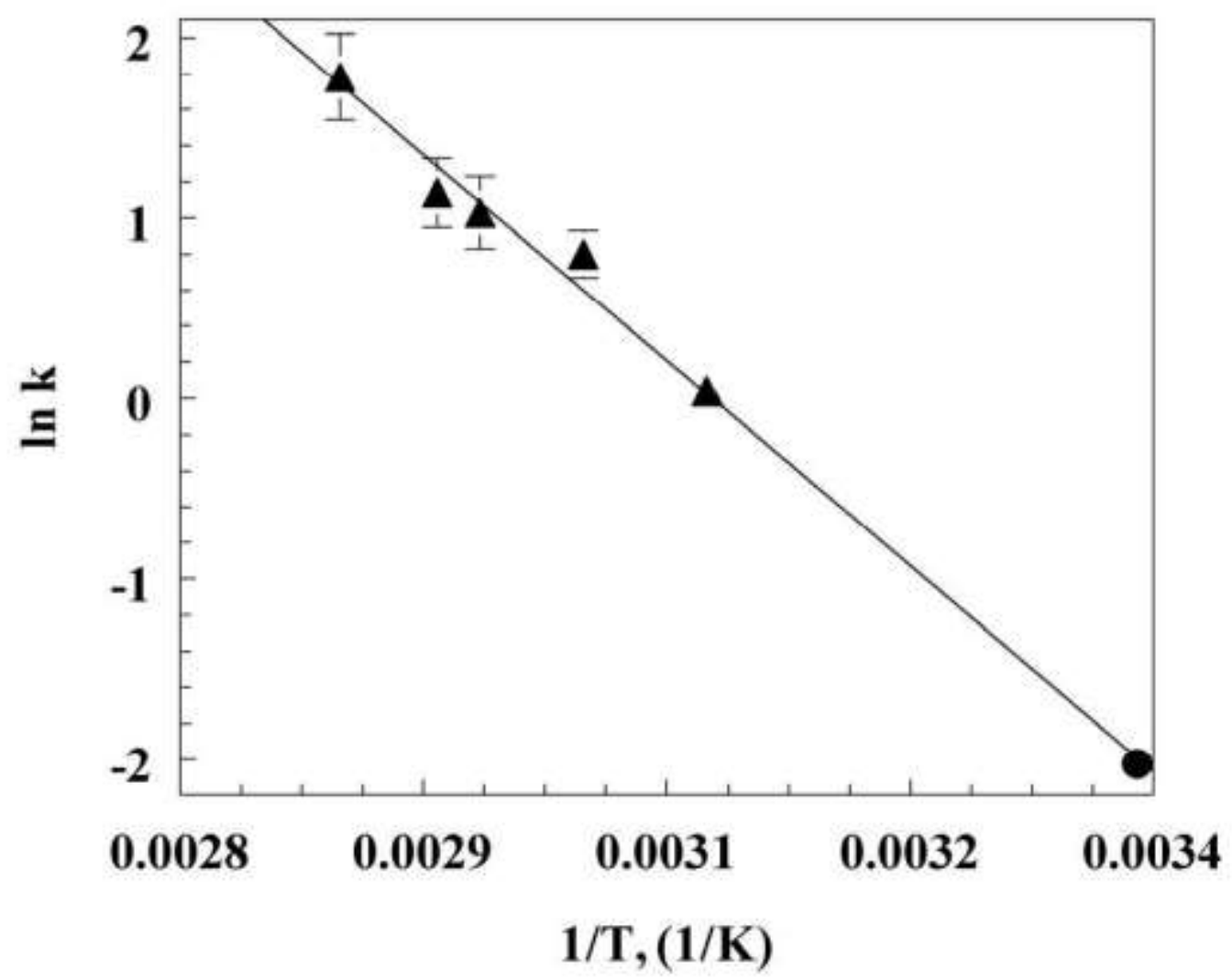

Journal of Porphyrins and Phthalocyanines, Vol. 11, No. 7 (2007): pg. 519-523. DOI. This article is @ Wiley and permission has been granted for this version to appear in e-Publications@Marquette. Wiley does not grant permission for this article to be further copied/distributed or hosted elsewhere without the express permission from Wiley. 
Figure 3. Cyclic voltammetry of $0.50 \mathrm{~m} \underline{\mathrm{M}} \mathrm{Fe}(\mathrm{TPP})(\mathrm{Cl})$ in DMF. A. 0.10 M TBAP; B. 0.10 M TEAP; C. 0.10 M TMAP. Scan rate: $1 \mathrm{mV} / \mathrm{s}$; electrode: glassy carbon; reference electrode: $\mathrm{Ag} / \mathrm{AgClO}{ }_{4}$ in acetonitrile; temperature: $22^{\circ}$.

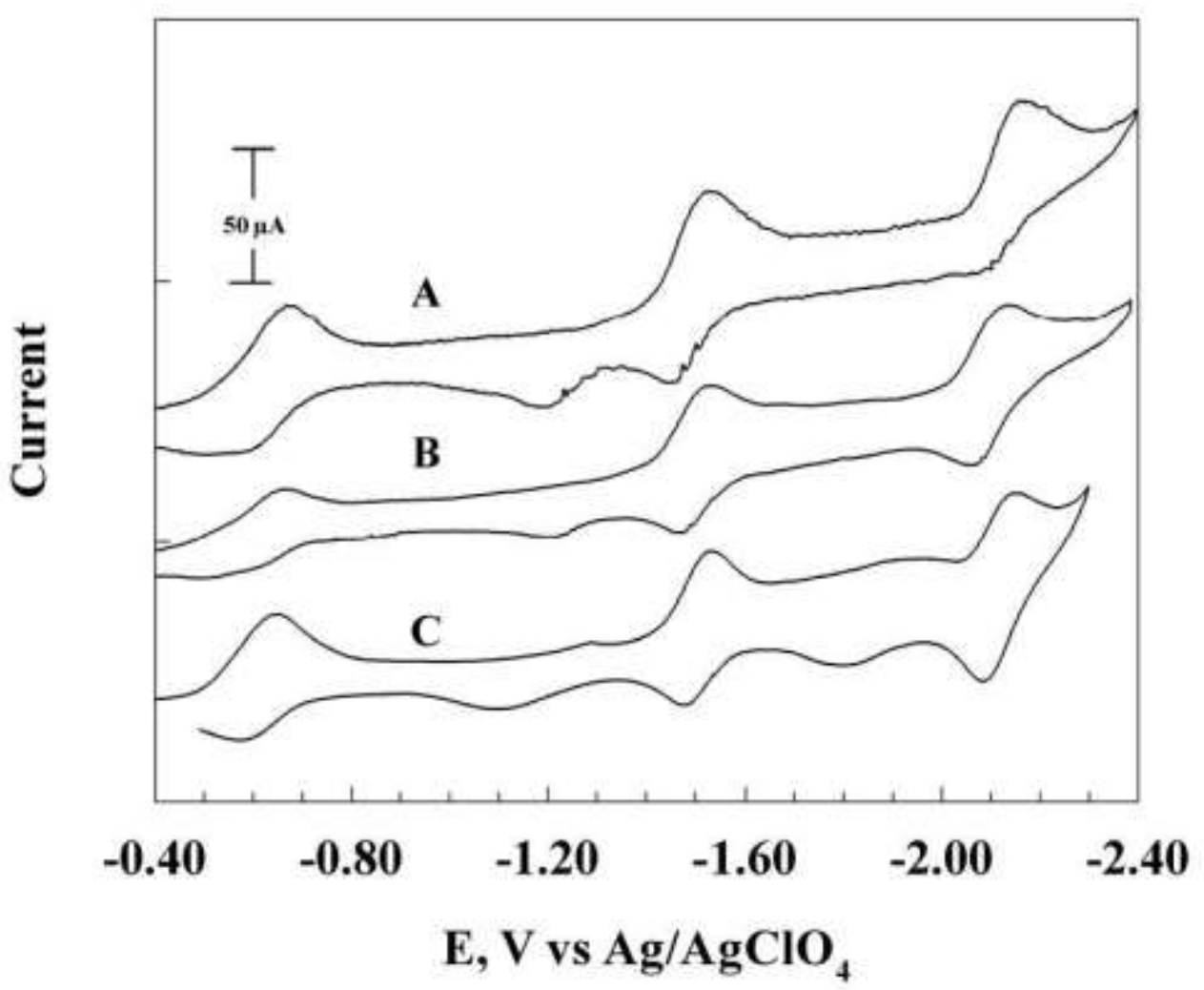

Journal of Porphyrins and Phthalocyanines, Vol. 11, No. 7 (2007): pg. 519-523. DOI. This article is (C Wiley and permission has been granted for this version to appear in e-Publications@Marquette. Wiley does not grant permission for this article to be further copied/distributed or hosted elsewhere without the express permission from Wiley. 
NOT THE PUBLISHED VERSION; this is the author's final, peer-reviewed manuscript. The published version may be accessed by following the link in the citation at the bottom of the page.

\section{Reference List}

1. DeSilva, C., Czarnecki, K., and Ryan, M. D., Inorg. Chim. Acta 1994; 226: 195-201.

2. Aurbach, D. and Gottlieb, H., Electrochim. Acta 1989; 34: 141-156.

3. Saveant, J. M. and Su, B. K., J. Electroanal. Chem. 1978; 88: 27-41.

4. Dahm, C. E. and Peters, D. G., J. Electroanal. Chem. 1996; 402: 91-96.

5. Kunkely, H. and Vogler, A., Z. Naturforsch. ,B: Chem. Sci. 2001; 56: 431432.

6. Lexa, D., Mispelter, J., and Saveant, J.-M., J. Am. Chem. Soc. 1981; 103: 6806-6812.

7. Lexa, D., Saveant, J.-M., and Wang, D. L., Organometallics 1986; 5: 14281434.

8. Gueutin, C., Lexa, D., and Saveant, J. M., J. Electroanal. Chem. 1988; 256: 223-227.

9. Hammouche, M., Lexa, D., Saveant, J. M., and Momenteau, M., J. Electroanal. Chem. 1988; 249: 347-351.

10. Bhugun, I., Lexa, D., and Saveant, J. M., J. Am. Chem. Soc. 1994; 116: 5015-5016.

11. Bhugun, I., Lexa, D., and Saveant, J. M., J. Am. Chem. Soc. 1996; 118: 1769-1776.

12. Bhugun, I., Lexa, D., and Saveant, J. M., J. Am. Chem. Soc. 1996; 118: 3982-3983.

13. Lexa, D., Saveant, J.-M., Su, K.-B., and Wang, D.-L., J. Am. Chem. Soc. 1988; 110: 7617-7625.

14. Lexa, D., Saveant, J. M., Schaefer, H. J., Su, K. B., Vering, B., and Wang, D. L., J. Am. Chem. Soc. 1990; 112: 6162-6177.

15. Gordon, J. E., J. Org. Chem. 1965; 30: 2760-2763.

16. Gordon, J. E. and Varughese, P., J. Chem. Soc. ,Chem. Commun. 1971; 1160-1161.

17. Missan, S. R., Becker, E. I., and Meites, L., J. Chem. Soc. 1961; 58-61.

18. Luder, W., Kraus, P. B., Kraus, C. A., and Fuoss, R. M., J. Am. Chem. Soc. 1936; 58: 255-258.

19. Lin, X. Q. and Kadish, K. M., Anal. Chem. 1985; 57: 1498-1501.

20. Nicholson, R. S. and Shain, I., Anal. Chem. 1964; 36: 706-723.

21. Arnett, E. M. and Reich, R., J. Am. Chem. Soc. 1980; 102: 5892-5902.

22. Balch, A. L., Cornman, C. R., Safari, N., and Latos-Grazynski, L., Organometallics 1990; 9: 2420-2421.

Journal of Porphyrins and Phthalocyanines, Vol. 11, No. 7 (2007): pg. 519-523. DOI. This article is @ Wiley and permission has been granted for this version to appear in e-Publications@Marquette. Wiley does not grant permission for this article to be further copied/distributed or hosted elsewhere without the express permission from Wiley. 